\title{
Epidemiology of Sheep Nematodes in Sub-Arctic Greenland: Sources of Infection on Rangeland Grazing
}

\author{
By C. H. Rose and D. E. Jacobs
}

State Veterinarian, Qaqortoq, Greenland and the Department of Veterinary Pathology, The Royal Veterinary College, University of London, United Kingdom.

\begin{abstract}
Rose, C. H. and D. E. Jacobs: Epidemiology of sheep nematodes in sub-Arctic Greenland: Sources of infection. Acta vet. scand. 1990, 31, 339-345. - Sources of nematode infection on the rangelands of a southern Greenlandic sheep farm were investigated as a part of a study of the epidemiology of Ostertagia and Nematodirus infections in a sub-arctic climate. Herbage larval counts were performed on samples collected from selected localities on the rangeland and post mortem wormcounts made on tracer lambs that had grazed these areas for the latter part of the summer season. Relatively high concentrations of larvae were found in good quality native grasses at sea-level and in grasses growing beneath canopies of willowshrub at higher altitudes. In general, however, the infectivity of the vegetation was very low and the pick-up of infection by the tracer lambs was correspondingly small.
\end{abstract}

Ostertagia; Nematodirus; epidemiology.

\section{Introduction}

Between the inland ice-cap and the west coast of southern Greenland lies $7000 \mathrm{~km}^{2}$ of mountainous terrain encompassing 2500 $\mathrm{km}^{2}$ of vegetation, adequate to support 25,000 sheep. Information on local sheep husbandry is provided by Rose et al. (1984a) who also make reference to the vegetation and grazing utilisation surveys published by Egede \& Thorsteinsson (1982, 1983). Despite the harsh climate and low stocking densities, a post mortem survey revealed fat lambs that harboured over 6000 Ostertagia and 25000 Nematodirus (Rose et al. 1984b). A study was therefore made to identify possible sources of infection on the extensive open rangeland.

\section{Materials and methods}

Site

The Upernaviarssuk Agricultural Research
Station lies on a peninsula some $16 \mathrm{~km}$ long and $5 \mathrm{~km}$ wide in the Qaqortoq Fjord $8 \mathrm{~km}$ east of Qaqortoq. The lower hillside closest to the homestead is fenced to form two paddocks of approximately 48 and 28 ha, while the remainder is unfenced rangeland rising to an altitude of $525 \mathrm{~m}$. Much of the land is rocky and barren but there are 4230 ha of vegetation suitable for grazing. The land is stocked at $38 \%$ of the theoretical maximum, i.e. a total of 345 sheep units (one unit being a ewe and 1.5 lambs).

Five areas were chosen for the study (Fig. 1): the two fenced paddocks, the open southwest facing rangeland adjacent to the paddocks (overlooking Upernaviarssuk) and two more distant upland areas, one on the north of the peninsula (overlooking Tasiussaq) and the other with a south-eastern aspect (overlooking Kanasut). 


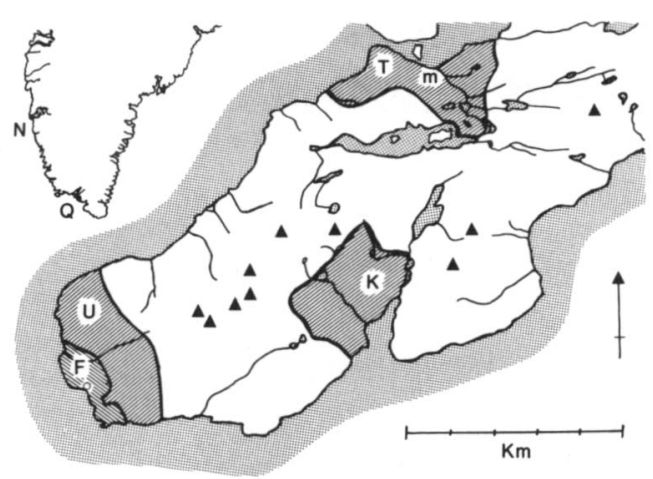

Figure 1. Map of the Upernaviarssuk peninsula in the Qaqortoq fjord. Key: $\mathrm{O}=$ Agricultural Research Station; $F=$ fenced paddocks; $U$ = rangeland grazing close to homestead; $\mathrm{K}=$ Kanasut area; $\mathrm{T}=$ Tasiussaq area; $\mathrm{m}=$ mouth of stream where heaviest parasite contamination was found. $\Delta=$ peaks over $400 \mathrm{~m}$.

Inset: southern part of Greenland; $Q=$ Qaqortoq (Julianehåb); $\mathrm{N}=$ Nuuk (Godthåb).

\section{Climate}

The climate is sub-arctic with long term mean monthly temperatures from January to December of $-4.7,-4.1,-4.1,0.4,3.7$, $5.3,7.6,7.8,5.9,1.7,-2.1$ and $-4.7^{\circ} \mathrm{C}$, respectively. Precipitation patterns vary greatly from year to year but mean monthly figures from January to December are: 46.0, $40.1,46.1,68.0,47.4,73.6,95.6,102.9$, $86.7,67.4,80.8$ and $77.1 \mathrm{~mm}$. The ground is often covered with snow from December to April.

\section{Herbage samples}

In view of the large expanse of land, difficulties of access and the sparsely distributed vegetation, it was not possible to traverse the grazing area systematically as would be done for a lowland pasture. In each of the chosen areas, therefore, sampling sites were chosen to represent the various types of locality and plant populations that might be utilised by sheep. In all, herbage samples weighing from
50 to $350 \mathrm{~g}$ were collected from 50 sites during late August 1985. A record was kept of evidence of recent grazing and of the vegetation quality which was subjectively assessed as follows:

Class 1 - dense growth with a relative abundance of grass varieties.

Class 2 - mixed plant population with a lesser abundance of grass varieties.

Class 3 - poor grazing with paucity of grass.

\section{Tracer lambs}

The infectivity of the vegetation in the fenced paddocks and on the open rangeland was also assessed by measuring the establishment of worms in tracer lambs. No facilities were available for the conventional production of worm-free lambs and so to achieve this goal 12 pairs of twin lambs and their ewes were kept on a nearby previously ungrazed island from birth (May) until midAugust 1985. The ewes had been treated with fenbendazole in March (Panacur, Hoechst) and all animals were treated twice with an oral ivermectin formulation (Oramec, Merck Sharp and Dohme) during their stay on the island. In mid-August, the lambs were marked for easy recognition and moved to the peninsula. Faecal samples taken at this time were all negative for nematode eggs. Three pairs of lambs were placed on each of 2 fenced paddocks while the remaining 6 pairs were turned onto the open rangeland. Post mortem worm-counts were performed after a further 6 weeks when the flock was collected for the autumn gathering.

\section{Parasitological techniques}

Nematode larvae were recovered from herbage samples by the method of Lancaster (1970), identified to genus level and counted. Results were expressed as the number of larvae per $\mathrm{kg}$ herbage (wet weight). Faecal eggcounts were performed by the McMaster 
Table 1. Numbers of larvae recovered per kg herbage, related to source and quality of vegetation.

\begin{tabular}{|c|c|c|c|c|c|c|c|c|c|}
\hline \multirow{2}{*}{$\begin{array}{l}\text { Genus } \\
\text { Vegetation* }\end{array}$} & & \multicolumn{4}{|c|}{ Ostertagia } & \multicolumn{4}{|c|}{ Nematodirus } \\
\hline & & 1 & 2 & 3 & $\begin{array}{c}\text { Combined } \\
\text { results }\end{array}$ & 1 & 2 & 3 & $\begin{array}{c}\text { Combined } \\
\text { results }\end{array}$ \\
\hline \multirow{3}{*}{$\begin{array}{l}\text { Fenced } \\
\text { paddocks }\end{array}$} & mean & 19.5 & 7.5 & 8.5 & 11 & 31 & 10.5 & 38.5 & 28 \\
\hline & range & $17-22$ & $0-30$ & $8-9$ & $0-30$ & $14-48$ & $0-42$ & $0-77$ & $0-77$ \\
\hline & no + ve & $2 / 2$ & $1 / 4$ & $2 / 2$ & $5 / 9$ & $2 / 2$ & $3 / 4$ & $1 / 2$ & $7 / 9$ \\
\hline \multirow[t]{3}{*}{ Upernaviarssuk } & mean & 6 & 29.5 & 12 & 18 & 18 & 44 & 31 & 32 \\
\hline & range & $0-16$ & $0-116$ & $0-67$ & $0-116$ & $0-40$ & $0-150$ & $0-67$ & $0-150$ \\
\hline & no $+v e$ & $3 / 6$ & $7 / 8$ & $3 / 4$ & $13 / 18$ & $5 / 6$ & $7 / 8$ & $3 / 4$ & $15 / 18$ \\
\hline \multirow[t]{3}{*}{ Kanasut } & mean & - & 9 & - & 11.5 & - & 21.5 & - & 30 \\
\hline & range & - & $0-25$ & 10 & $0-25$ & - & $0-108$ & 100 & $0-108$ \\
\hline & no $+v e$ & - & $7 / 8$ & $1 / 1$ & $8 / 9$ & - & $6 / 8$ & $1 / 1$ & $7 / 9$ \\
\hline \multirow[t]{3}{*}{ Tasiussaq } & mean & 325 & 67.5 & 2.5 & 145 & 31 & 33.5 & 5.5 & 35 \\
\hline & range & $6-1175$ & $0-360$ & $0-5$ & $0-1175$ & $0-208$ & $0-86$ & $5-6$ & $0-208$ \\
\hline & no + ve & $5 / 5$ & $5 / 8$ & $1 / 2$ & $11 / 15$ & $5 / 5$ & $6 / 8$ & $2 / 2$ & $13 / 15$ \\
\hline \multirow{3}{*}{$\begin{array}{l}\text { Combined } \\
\text { results }\end{array}$} & mean & 131 & 32 & 9 & 54 & 32 & 31 & 35 & 32 \\
\hline & range & $0-1175$ & $0-360$ & $0-67$ & $0-1175$ & $0-208$ & $0-150$ & $0-77$ & $0-208$ \\
\hline & no + ve & $10 / 13$ & $20 / 28$ & $7 / 9$ & $37 / 50$ & $12 / 13$ & $22 / 28$ & $7 / 9$ & $41 / 50$ \\
\hline
\end{tabular}

* Quality of vegetation 1 = best, 3 = worst. See text for definitions.

technique. At slaughter, worms in $2 \%$ aliquots were counted after washing the abomasal and small intestinal contents over a $150 \mu \mathrm{m}$ sieve, while the mucosae were subjected to acid-pepsin digestion before being washed over a $38 \mu \mathrm{m}$ sieve.

\section{Results}

\section{Herbage samples}

Trichostrongylid larvae were recovered from 48 of the 50 herbage samples $(96 \%)$. Ostertagia spp larvae were found in 37 (74\%) and Nematodirus spp in 41 (82\%). Generally, the herbage larval counts were exceedingly low with 44 samples $(88 \%)$ yielding fewer than 50 Ostertagia larvae per $\mathrm{kg}$ herbage and $40(80 \%)$ fewer than 50 Nematodirus per kg. However, 3 samples provided counts of over 300 Ostertagia larvae per kg herbage and three gave more than 100 Nematodirus per $\mathrm{kg}$. The highest figures recorded were 1175 Ostertagia larvae per $\mathrm{kg}$ and $208 \mathrm{Ne}$ - matodirus larvae per $\mathrm{kg}$. The most heavily contaminated area appeared to be parts of the Tasiussaq rangeland while the fenced paddocks yielded the fewest Ostertagia larvae (Table 1). The combined results suggest that the poorer vegetation may have been less heavily infected with Ostertagia, but the mean Nematodirus counts were remarkably similar irrespective of the source of the sample or the quality of the herbage.

The herbage sample with the greatest density of both Ostertagia and Nematodirus larvae came from a heavily grazed area at the mouth of a stream where there was a moderately dense growth of fine grass with smaller quantities of coarse grass between boulders. The samples with the next two highest Ostertagia counts $\left(384\right.$ and $\left.3601 \mathrm{~kg}^{-1}\right)$ and the third highest Nematodirus count (108 1 $\mathrm{kg}^{-1}$ ) were taken from hillsides covered with willow-shrub (Salix glauca) with luxuriant native grasses growing beneath the canopy 


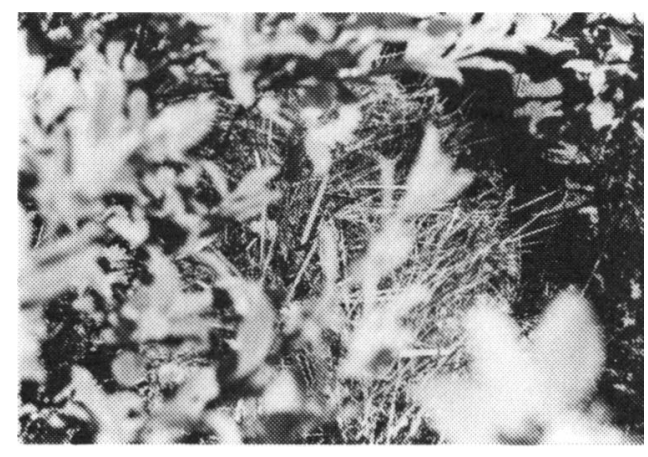

Figure 2. Native grasses growing under a canopy of willow-shrub (Salix glauca) provoding ideal conditions for development of nematode larvae.
(Fig. 2). The second highest Nematodirus count (150 $1 \mathrm{~kg}^{-1}$ ) occurred on a heavily grazed rangeland slope above the homestead.

\section{Tracer lambs}

All but one of the 24 tracer lambs were brought down with the autumn gathering of sheep on the peninsula. Worm burdens at the end of the six week grazing period were in all cases low with maximum counts of 850 and 2500 for Ostertagia spp and Nematodirus spp, respectively. Individual counts and the spectrum of species identified are displayed in Table 2. Some $19.8 \%$ of the

Table 2. Individual and mean worm counts of the slaughtered tracer lambs, together with species identified (in parenthesis).

\begin{tabular}{lllllc}
\hline & \multicolumn{3}{c}{ Fenced paddocks } & & \multicolumn{2}{c}{ Open rangeland } \\
\cline { 2 - 3 } \cline { 5 - 6 } & Ostertagia & Nematodirus & & Ostertagia & Nematodirus \\
\hline & $150(\mathrm{O})$ & $1800(\mathrm{Na} ; \mathrm{Ns})$ & & $200(\mathrm{O})$ & 0 \\
& $400(\mathrm{Oc})$ & $300(\mathrm{~N})$ & & $150(\mathrm{Oc})$ & $350(\mathrm{Ns})$ \\
& $850(\mathrm{Oc})$ & $800(\mathrm{Na} ; \mathrm{Ns})$ & & $100(\mathrm{Oc})$ & $450(\mathrm{Ns})$ \\
& $300(\mathrm{Ot})$ & $50(\mathrm{Ns})$ & & $250(\mathrm{Oc} ; \mathrm{Ot})$ & $550(\mathrm{Ns})$ \\
& $150(\mathrm{O})$ & 0 & & $50(\mathrm{Oc})$ & $350(\mathrm{Ns})$ \\
& $850(\mathrm{Oc} ; \mathrm{Td})$ & $400(\mathrm{Ns})$ & & 0 & $700(\mathrm{Ns})$ \\
& $100(\mathrm{O})$ & $2500(\mathrm{Na} ; \mathrm{Ns})$ & & 0 & 0 \\
& $150(\mathrm{O})$ & $950(\mathrm{Ns})$ & & 0 & 0 \\
& $400(\mathrm{Oc})$ & $600(\mathrm{Ns})$ & & $150(\mathrm{O})$ & $50(\mathrm{~N})$ \\
& $450(\mathrm{O})$ & $450(\mathrm{Ns})$ & & 0 & $150(\mathrm{Ns})$ \\
& $250(\mathrm{Oc})$ & $700(\mathrm{Ns})$ & & $300(\mathrm{O})$ & $300(\mathrm{~N})$ \\
mean & 368 & & & $300(\mathrm{Oc})$ & $1400(\mathrm{Ns})$ \\
no + ve & $11 / 11$ & $10 / 11$ & 116 & 358 \\
\hline
\end{tabular}

Student $\mathrm{t}$ test: Ostertagia $\mathrm{p}<.01 ;$ Nematodirus NS.

$\mathrm{O}$ : ostertagid species (Identification not possible as all worms in aliquot either female or immature)

Oc: Ostertagia circumcincta

Ot: Ostertagia trifurcata

$\mathrm{N}$ : Nematodirus sp (Identification not possible as all worms in aliquot either female immature)

Na: Nematodirus abnormalis

Ns: Nematodirus spathiger

Td: Teladorsagia davtiani 
Ostertagia were larval forms, while virtually all of the Nematodirus were adult. No other genera were identified. Counts for the rangeland lambs tended to be lower than for lambs in the fenced paddocks, several in the former group being virtually worm-free. $N$. abnormalis was recovered from both fenced paddocks but not from the open rangeland.

\section{Discussion}

Obviously, 50 herbage samples from an area of some $80 \mathrm{~km}^{2}$ does not constitute a comprehensive survey and the collection points were of necessity highly selected. However, as relatively little information has been published on sheep nematodes in sub-arctic regions, this provides an insight into the epidemiology of such infections. The scale of the project was limited by the terrain and prevailing weather conditions but attempts were made to sample a variety of locations and vegetation types that might be grazed by free-ranging sheep.

The end of August was chosen for this exercise as earlier field studies (Rose et al. 1984) had shown that the output of both trichostrongylid and Nematodirus eggs in the faeces of Greenlandic lambs increases at this time suggesting that infection is occurring. Furthermore, studies at Qaqortoq in which plots of herbage on a hay-field were experimentally contaminated with infected faeces confirm that larvae are reaching the infective stage of their development during this period (Rose \& Jacobs 1990).

Results in Table 1 are expressed in terms of wet weight of vegetation as there were no local facilities for drying herbage. Wet weights provide a less accurate indication of larval challenge as the appetite of ruminants is governed by the dry matter content of their food rather than the gross weight. Remarkably, $96 \%$ of the collected herbage samples yielded infective larvae suggesting that there is widespread contamination of the rangeland despite the low stocking density. A more constant pattern was detected for Nematodirus than Ostertagia (Table 1). This probably reflects the fact that eggs of the former are cold tolerant (Ash \& Atkinson 1986) and do not develop synchronously so that larvae can occur on the herbage for up to 3 years after faecal deposition (Rose \& Jacobs 1990).

The numbers of infective larvae on the herbage were, however, generally very low, a result that might have been influenced by dry weather in the 2 weeks prior to the survey. Relatively high counts (equivalent to approximately 6000 Ostertagia and 1100 Nematodirus larvae per $\mathrm{kg}$ dried herbage) were found only at sea-level on a small area of native grasses that almost resembled a lowland pasture. Otherwise, the higher counts were mostly associated with grasses flourishing under a canopy of willow-shrub growing to a height of $30-80 \mathrm{cms}$ and providing a humid, sheltered environment for nematode development (Fig. 2).

The low worm burdens of the tracer lambs could be a consequence of acquired immunity but this is thought unlikely as the lambs were reared under conditions designed to minimise prior exposure. The worm-counts therefore confirm the generally low level of infectivity of the vegetation and indicate that larval densities did not increase significantly in the weeks between the rangeland survey and slaughter. The trend to higher infection in the lambs from the fenced paddocks is in apparent contradiction to the higher larval counts obtained from some rangeland herbage samples. This may indicate that the fenced paddocks were inadequately surveyed, only 9 samples being taken from that area. Alternatively, as there was no way of controlling or recording the behaviour of the 
tracers after turnout onto peninsula, it is possible that none of the free-ranging lambs had grazed in the more heavily infected localities. Confinement to the fenced paddocks could also have restricted choice, particularly as these animals were kept at a relatively higher stocking density.

Lambs will be voiding relatively large numbers of Ostertagia and Nematodirus eggs onto the rangeland in the latter part of the summer grazing season (Rose et al. 1984) but the fenced paddocks are normally reserved for overwintering the breeding ewes. This land is therefore grazed at a different time of year, by a different class of stock and at a much higher stocking rate than is the case with the open rangeland, and this will influence the respective patterns of contamination. This may explain the apparent occurrence of $N$.abnormalis here but not on the rangeland. It is more likely, however, that the numbers of animals used were too small to give a representative picture of the spectrum of species. For example Nematodirus helvetianus has been recovered at post mortem examination from ewe-lambs in the Upernaviarssuk flock (Jacobs \& Rose unpublished data) but this species did not appear in the tracer lambs. Adult stock are solidly immune to Nematodirus and so the only source of winter infection with this genus after the fat lambs are slaughtered will be the young replacement ewes. The fenced areas are in use until after lambing in May and so contamination with Ostertagia would be expected to take place as a consequence of the periparturient egg-rise. However, the ewes are routinely treated with anthelmintic in February or March to prevent this occurrence, which probably explains why higher levels of contamination were not found at this site.

Ostertagia and Nematodirus were the sole nematode genera represented in the present investigation. This is in accord with earlier post mortem findings (Rose et al. 1984) when the only other species found in the upper alimentary tract was Trichostrongylus capricola which was present only in very small numbers. Helle (1970) compared the nematode populations of sheep in different parts of Norway and noted that the spectrum of species diminished as the climate became harsher, a trend further exemplified by the surveys of Richter (1976) and Koller (1982) in Iceland and sub-arctic Norway, respectively.

\section{Conclusion}

Despite very low stocking densities, Ostertagia and Nematodirus larvae were ubiquitously found in the vegetation suitable for grazing on the extensive rangeland of a southern Greenlandic sheep farm. Relatively high concentrations of larvae were found in good quality grass at sea-level and in grasses growing beneath canopies of willow-shrub at higher altitudes. In general, however, the infectivity of the grazing was very low and the pick-up of infection by tracer lambs correspondingly small.

\section{Acknowledgements}

This work was made possible by a grant from the Wellcome Trust. The staff of the Upernaviarssuk Agricultural Research Station are thanked for their cooperation as are Mr Kai Egede and Professor P. Nansen for their support and encouragement. The authors are grateful to Dr. L. M. Gibbons for expert worm identification.

\section{References}

Ash C, Atkinson HJ: Nematodirus battus: development of cold hardiness in dormant eggs. Exp. Parasitol. 1986, 62, 24-28.

Egede $K$, Thorsteinsson I: Detail plan for făreavlen i Syd-Grønland. (Protocol for sheep production in southern Greenland). Report, Ministry for Greenland, Copenhagen, 1982. 
Egede $K$, Thorsteinsson I: Undersogelser af de naturlige græsgange i Syd-Grønland 1977-81. (Studies of natural pastureland in southern Greenland). Report: Landbrugets Forskningsinstitut, Island og Forsøgsstationen Upernaviarssuk, Grønland, 1983.

Helle $O$ : Parasittfaunaen hos sau på lavlandsbeite og $\mathrm{i}$ høyfjellet og dens innflytelse på sauens produksjonsevne. (The parasites of sheep from lowland and highland grazings and their influence on production). In: Proceedings 1st Nordic Veterinary Congress, Bergen, 22-25 July 1970.

Koller HG: Parasitter hos sau på Rienøya, Troms med vekt på gastro-intestinale nematode. (Parasites of sheep on Rienøya, Troms with particular reference to gastrointestinal nematodes). Thesis, Terrestrial ecology and zoology, University of Tromsø, 1982.

Lancaster $M B$ : The recovery of infective nematode from herbage samples. J. Helminstol. 1970, 44, 219-230.

Richter SH: Parasites in sheep and cattle in Iceland. Report, Institute for Experimental Pathology, University of Iceland 1976.

Rose CH, Jacobs DE, Jorgensen RJ, Nansen P: Studies on the helminth parasites of sheep in southern Greenland. Nord. Vet.-Med. 1984, 36, 77-87.

Rose CH, Jacobs DE: Epidemiology of Nematodirus infections of sheep in a sub-arctic climate: development and persistence of larvae on herbage. Res. Vet. Sci. 1990, 48, 327-330.

\begin{abstract}
Sammendrag
En epidemiologisk undersogelse af parasitiske nematoder hos fär $i$ subarktisk Gronland:

Vurdering af smittekilder på grasningsområder.

For at opnå en bedre indsigt i parasitiske nematoders epidemiologi $\mathrm{i}$ et subarktisk klimaområde, blev koncentrationen af Ostertagia spp. og Nematodirus spp. larver bestemt i vegetationsprøver, indsamlet på udvalgte lokaliteter $i$ et udstrakt fjeldgræsningsområde i Syd-Grønland. Derudover blev smitteoptagelsen vurderet i græsningssæsonens sidste 6 uger ved hjælp af "tracer"-lam. Den største koncentration af larver blev fundet $i$ en lavtliggende lokalitet med god græskvalitet ved udløbet af en å. På fjeldet var der især mange larver på steder, hvor græsset var overvokset af skyggegivende pil. Men generelt var græsningsarealernes smittegrad dog ganske lav, ligesom "tracer"-lammene kun optog moderate parasitbyrder.
\end{abstract}

(Received May 30, 1989; accepted October 18, 1989).

Reprints may be requested from: D. E. Jacobs, The Royal Veterinary College, Boltons Park, Potters Bar, Herts, EN6 INB, U. K. 